\title{
Analysis of the Causality Links between the Growth of the Construction Industry and the Growth of the Nigerian Economy
}

\author{
"Mu'awiya Abubakar', Muhammad Abdullahi² and Kabir Bala'
}

Published online: 31 August 2018

To cite this article: Mu'awiya Abubakar, Muhammad Abdullahi and Kabir Bala (2018). Analysis of the causality links between the growth of the construction industry and the growth of the Nigerian economy. Journal of Construction in Developing Countries, 23(1): 103-113. https://doi.org/10.21315/jcdc2018.23.1.6.

To link to this article: https://doi.org/10.21315/jcdc2018.23.1.6

\begin{abstract}
The construction industry makes a significant contribution to the growth and development of every economy, by providing infrastructure for other productive ventures, shelter to the citizens and generating employment to people of different levels of knowledge and skills. In Nigeria, the construction industry contributes an average of over $3 \%$ to the annual gross domestic product and an average of about one-third of the total fixed capital investment. Despite the huge potentials of the Nigerian construction industry, little attention is given to its significance in driving the Nigerian economy to greater heights. This study explored the empirical evidence of causal relationship between the growth and development of the Nigerian economy and that of the construction sector. Econometric techniques such as unit root test, Granger causality test and Johansen's co-integration test were conducted to establish the actual relationship between the output of the construction sector (CS) and the gross domestic product (GDP) of the country. Twenty six years' time series data for the CS and the GDP between 1990 to 2015 was obtained from the statistics database of the Central Bank of Nigeria (CBN) and used for the analyses. The research revealed that despite the harsh economic realities facing the country in recent times, there exist a bi-directional linkage between the CS and the GDP of Nigeria. Each of them precedes the other by one year. The study recommends that any effort to diversify the Nigerian economy should consider revamping the construction industry for improved productivity in order to benefit from its significant positive effects on the economy.
\end{abstract}

Keywords: Construction sector, Gross domestic products, Granger causality test, Economy

\section{INTRODUCTION}

The construction industry makes a vital contribution to the competitiveness and prosperity of the economy. A modern and efficient infrastructure is a key driver of productivity, and the construction industry has a major role in delivering the built infrastructure in an innovative and cost effective way. It is also a key player in providing shelter and employment to a large number of the people with different levels of knowledge and skills (Omole, 2000; Ogbebor, 2002).

The construction industry can be described in a number of ways (Myers, 2008). In broad sense, it is seen to comprise the wide range of entities and activities that directly or indirectly contribute to the actualisation of built infrastructure. These include suppliers of basic materials (e.g. cement and bricks), machinery manufacturers who

'Department of Building, Faculty of Environmental Design, Ahmadu Bello University, Zaria, Kaduna State, NIGERIA

${ }^{2}$ Department of Quantity Surveying, Faculty of Environmental Design, Ahmadu Bello University, Zaria, Kaduna State, NIGERIA

"Corresponding author: muawiyaabubakar@abu.edu.ng 
provide equipment used on site, (e.g. such as cranes and bulldozers), site operatives (both skilled and unskilled) who put components and materials together, project managers and all professionals (i.e. architects, builders, engineers and surveyors) who design and co-ordinate the overall assembly. Others are the fabricators of building components, e.g. windows and doors, facility managers who manage and maintain the property and providers of complementary goods and services such as transportation, distribution, demolition, disposal and clean-up (Manseau and Seaden, 2001). On the other hand the construction industry is narrowly considered to involve entities and processes that just construct and maintain housing, infrastructure, residential, commercial and industrial structures. Incidentally, the later definition of the construction industry used for sectoral classification by government and other agencies (such as the government of the United Kingdom and the United Nations) in determining the relationship between the sectors and the economies of countries and regions over the world (Myers, 2008). In any sense of it, the construction industry has been reported to be a very significant contributor to national economies considering its capacity for employment and its support for all other economic entities of the countries.

In Nigeria, the construction industry continues to impact positively on the living condition and economy of the country. Further, considering the huge housing and infrastructure deficit in areas of airports, railways, road networks and industries, the construction industry stands an important place in supporting the economy and increasing its opportunities for growth and development (Oluwakiyesi, 2011 ).

However, despite the huge potentials of the Nigerian construction industry, little attention is given to its real significance in the much needed economic expansion of the country and the likelihood of leading the economy to prosperity. Khan (2008) studied the role of the construction industry in the economic growth of Pakistan, and found a uni-directional relationship between two variables. Anaman and Osei-Amponsah (2007) examined the causal relationship between the growth of the Ghanaian macro economy and its construction industry, and found the industry with the potential for driving the economy to significant growth. Similar result was found by Oladinrin, Ogunsemi and Aje (2012), who investigated the role of the Nigerian construction sector in economic growth of the country from year 1990 to 2009. Nevertheless, Nigeria has faced serious economic challenges in recent times as a result of dwindling revenue occasioned by the drastic fall in oil prices at the international market, leading to a reduction of about $40 \%$ in exports and a rising inflation (International Monetary Fund [IMF], 2016). These challenges have been seen to affect the relationship between the construction sector and the country's gross domestic product (GDP). It is pertinent to empirically re-examine the causality between Nigeria's construction sector and the GDP, to get an insight in the relationship between the two variables. This paper examines the relationship between the construction sector output (growth) and that of the Nigerian GDP with a view to investigate whether or not the economic challenges of the country have any negative effect on their causal linkage. The remaining part of the paper discusses the nature of the construction industry and its significance to the aggregate economy, followed by the research methods, results and discussion, then conclusion and recommendations. 


\section{THE CONSTRUCTION INDUSTRY}

The construction industry is one of the major drivers of the economic growth of developing countries. The diverse nature of the industry enables it to mobilise and effectively utilise human and material resources: draw the expertise of the various construction stakeholders and in addition a major consumer of the products of the manufacturing sector. It also plays critical roles in the development and maintenance of housing and infrastructure which promotes local employment and improves economic efficiency (Anaman and Osei-Amponsah, 2007). The contribution of construction industry to national economy as stated by Field and Ofori (1988) is quite significant in that it generates employment and incomes for the people and changes in the industry directly affect the entire economy of a nation (Chen, 1998; Rameezdeen, 2007). On that basis, researchers have hypothesised a strong linkage between construction output (CO) and GDP, implying that whatever happens to the industry will directly and indirectly influence other industries and ultimately, the wealth of a country. Therefore, the industry is regarded as a major contributor to the nations' economic growth (Field and Ofori, 1988).

In Nigeria, despite construction's impact on the national economy, the trend of its growth in relation to the GDP still remains abysmal. According to Central Bank of Nigeria's (CBN) statistical estimates as at the end of the year 2015, the Nigerian construction sector contributes $3.88 \%$ to the national GDP (CBN, 2016). Figure 1 shows that despite the sector's significant growth in terms of Compound Annual Growth Rate (CAGR), its contribution to national GDP has remained statically low. The construction industry report (Oluwakiyesi, 2011) revealed that in year 1981, the construction sector accounted for $5.8 \%$ of the national GDP and in the last three decades, Nigeria's total GDP has increased to approximately 495 times its size. On the contrary, construction sector GDP has only grown to 125 times its size in year 1981. As it has always been, the key drivers of the nation's GDP over the last three decades still remain the same-Agriculture, crude oil production and Trade. In comparison to other sectors, the construction industry in Nigeria even as it produces nearly $70 \%$ of the nation's fixed capital formation (Idrus and Sodangi, 2007) is yet to realise its potential in spite of the country's huge infrastructural deficit.

Meanwhile, the construction sector of other oil producing countries but which are less diversified economies, such as Saudi Arabia and the United Arab Emirates (UAE) and more diversified oil producers like Russia have experienced considerable boom (Oluwakiyesi, 2011). For example, in the UAE, the oil boom in early 1970's skyrocketed the construction sector of the UAE and which successfully managed the country's infrastructural development amidst falling oil price in the 1980's. The rapid increase in oil fuelled economic growth, favorable demographic fundamentals, growing commercial activities and tourism have caused substantial construction boom in these countries (Oluwakiyesi, 2011).

By year 2009, UAE's construction sector has grown very rapidly with construction accounting for almost $11 \%$ of its GDP. They saw the need to take advantage of the rising oil prices in the world market to sustain their infrastructure which the construction sector has tremendously benefitted from. Figure 2 shows some oil producing countries and their construction sector's GDP. 


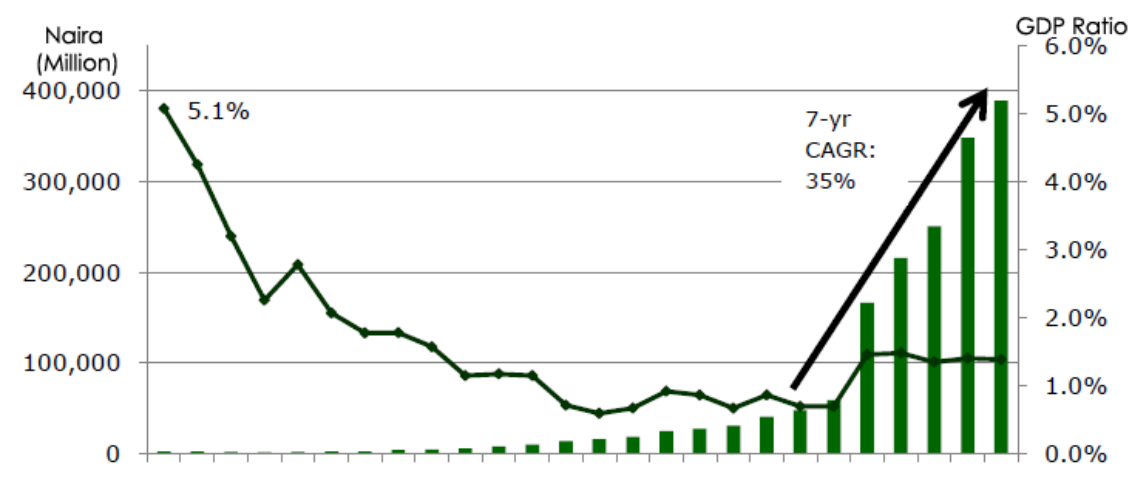

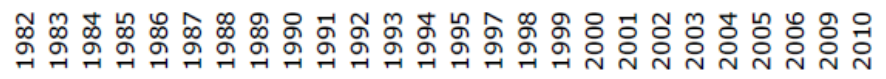

Building \& Construction sector GDP Contribution to total GDP

Figure 1. Nigeria Construction GDP

Source: Oluwakiyesi (2011)

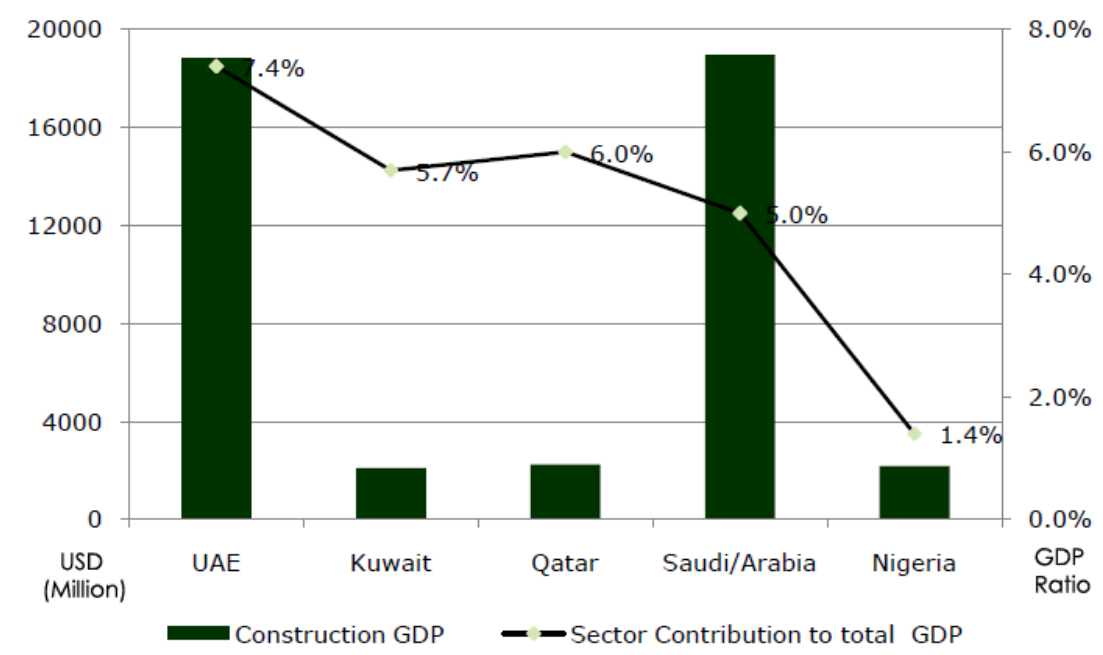

Figure 2. Some Organisation of the Petroleum Exporting Countries (OPEC) Members Construction Sector GDPs

Source: Oluwakiyesi (2011) 


\section{RESEARCH METHODS}

This study examines the relationship between the construction sector output (growth) and that of the Nigerian GDP with a view to finding out whether or not the economic challenges of the country have any negative effect on their causal linkage. To investigate the causal relationship between CO and GDP in Nigeria data spanning over a period of 26 years (year 1990 to 2015) was obtained from the statistical database of the CBN. The data is based on year 2010 annual constant basic prices (million/Naira). Descriptive statistics and econometric techniques were used to analyse the general properties of the data and the relationship between GDP and CO respectively. To evaluate the causal relationship between the economic variables in this study, stationarity of the data set used was first examined using Augmented Dicky Fuller (ADF) test on each of the series. This was basically to ensure that the data is non-stationary and have no unit roots. A stationary time series data is one whose statistical properties are all constant over time. This refers to the existence of unit roots in the econometric data, which makes hypothesis test results unreliable and inaccurate (Dicky and Fuller, 1979). Data stationarity in econometrics is achieved through a process known as "differencing" (Granger and Newbold, 1974), which involves the computation of differences between the current value and that of the previous period.

Using Granger causality methodology, the stationary data was subsequently analysed to verify whether historical variations of the $\mathrm{CO}$ follow or precede the GDP. Granger causality test was conducted to examine the lead lag relationships between CO and GDP. Moreover, because the variables were found to be nonstationary at the normal level, Johansen's (1988) co-integration test (Khan, 2008) was used to examine the existence of long run relationship between the variables (the GDP and the CO). Eviews software (version 8 ) was used to run all the tests (ADF unit root test, Granger test and the co-integration test).

To check whether GDP and CO have unit roots, the three Dicky Fuller Models shown in Equations 1, 2 and 3 were tested.

$$
\begin{aligned}
& \Delta \mathrm{GDP}_{26}=\mathrm{B1}+\triangle \mathrm{GDP}_{26}+\mathrm{ai}+\ldots \quad \text { (Intercept only) Eq. } 1 \\
& \Delta G D P_{26}=B 1+B 2+\Delta G D P_{26}+a i+\text { et } \quad \text { (Trend and intercept) Eq. } 2 \\
& \Delta G D P_{26}=\Delta G D P_{f}+a i+\text { et } \quad \text { (None) Eq. } 3
\end{aligned}
$$

where, $\Delta G D P_{t}$ is the change in GDP, in time $(t), B 1$ and $B 2$ are the intercepts (constants), ai and et stand for coefficients of intercept and trend respectively.

Similarly, the following equations were used for testing unit roots in the CO variable:

$$
\begin{array}{lll}
\Delta \mathrm{CO}_{26}=\mathrm{B} 1+\Delta \mathrm{CO}_{26}+\mathrm{ai}+\ldots & \text { (Intercept only) } & \text { Eq. } 4 \\
\Delta \mathrm{GDP}_{26}=\mathrm{B} 1+\mathrm{B} 2+\Delta \mathrm{CO}_{26}+\mathrm{ai}+\text { et } & \text { (Trend and intercept) } & \text { Eq. } 5 \\
\Delta G D P_{26}=\Delta \mathrm{CO}_{26}+\mathrm{ai}+\text { et } & \text { (None) } & \text { Eq. } 6
\end{array}
$$

where, $\Delta \mathrm{CO}_{26}$ is the change in $\mathrm{CO}$, in time $(t), \mathrm{B} 1, \mathrm{~B} 2$ are the intercepts (constants), ai and et stand for coefficients of intercept and trend respectively. 
These equations were tested based on the following hypotheses formulated:

1. For GDP:

$\mathrm{H1}$ : GDP is not stationary, or has unit roots.

$\mathrm{H}_{1}$ : GDP is stationary.

2. For $\mathrm{CO}$ :

$\mathrm{H} 2_{0}$ : $\mathrm{CO}$ is not stationary, or has unit roots.

$\mathrm{H} 2_{1}$ : $\mathrm{CO}$ is stationary.

3. Granger Causality Test: the following models were used for the test.
$\mathrm{GDP}_{26}=\mathrm{C}_{1} * \mathrm{COt}-1+\mathrm{C} 2 * \mathrm{GDPt}-\mathrm{j}+\mathrm{ult}$
$\mathrm{CO}_{26}=\mathrm{C} 3 * \mathrm{COt}-1+\mathrm{C} 4 * \mathrm{CO}_{26}-\mathrm{j}+\mathrm{ult}$

where, CO represents construction output, $t-1 / t-j$ for time lags and $u 1 t / u 2 t$ as residuals of the models.

The following hypotheses were formulated for testing the Granger's causality:

$\mathrm{H}_{3}$ : GDP does not cause $\mathrm{CO}$ and vice versa.

$\mathrm{H}_{1}$ : GDP does cause $\mathrm{CO}$ and vice versa.

These hypotheses were meant to evaluate the correlation that exists between the growth of the construction sector and the GDP of the country.

\section{RESULTS AND DISCUSSIONS}

The annual CO and GDP for the period of 26 years (i.e. year 1990 to 2015) was used for analysis in this study. The choice of 26 years was to satisfy the accuracy requirement of having at least 20 observations for any time series analysis (Khan, 2008). The CO and GDP data were expressed in millions of Naira. The correlation was examined to find out the evidence of Granger causality between the two variables. Table 1 shows the descriptive statistics, which explains the general properties and characteristics of the time series data.

Table 1. Descriptive Statistics

\begin{tabular}{lcc}
\hline \multicolumn{1}{c}{ Statistics } & CO & Total GDP \\
\hline Mean $(\mathrm{mN})$ & $1,059,518$ & $36,095,698$ \\
Median $(\mathrm{mN})$ & $769,594.2$ & $30,333,579$ \\
Maximum $(\mathrm{mN})$ & $2,680,216$ & $69,023,930$ \\
Minimum $(\mathrm{mN})$ & $442,274.2$ & $19,199,060$ \\
Std. dev. $(\mathrm{mN})$ & $682,221.9$ & $17,039,518$ \\
Skewness & 1.17798 & 0.642425 \\
Kurtosis & 3.135087 & 1.964002 \\
\hline
\end{tabular}

(continued on next page) 
Table 1. (continued)

\begin{tabular}{lcc}
\hline \multicolumn{1}{c}{ Statistics } & CO & Total GDP \\
\hline Jarque-Bera & 6.032862 & 2.951145 \\
Probability & 0.048976 & 0.228648 \\
Observations & 26 & 26 \\
\hline
\end{tabular}

\section{Unit Root Test}

In practice, the unit root test is used to test the stationarity of the data series, which helps in avoiding spuriousness of the regression. The test was conducted using ADF test based on Equations 1-6 in previous section. A stationary time series is one whose statistical properties are all constant over time. This refers to the existence of unit roots in the econometric data, which makes hypothesis test results unreliable and inaccurate (Dicky and Fuller, 1979). The results of the ADF test revealed that the data is non stationary at normal level. Therefore, to achieve stationarity, unit root test was conducted at first difference level for both CO and GDP. The result gave rise to the rejection of $\mathrm{H}_{0}$, which denote that the data in either case is stationary. This implies that the data is clean and fit for Granger causality test. This is important because it makes the results of further analyses valid and reliable.

Table 2. Result of Unit Root Test Using ADF

\begin{tabular}{lcccccc}
\hline \multirow{2}{*}{ Series } & \multicolumn{6}{c}{ ADF Test in First Difference } \\
\cline { 2 - 7 } & Intercept Only & Lag Order & $\begin{array}{c}\text { Intercept and } \\
\text { Trend }\end{array}$ & Lag Order & None & Lag Order \\
\hline CO & -2.99 & 1 & -3.61 & 1 & -1.96 & 1 \\
GDP & -2.64 & 1 & -3.24 & 1 & -1.61 & 1 \\
\hline
\end{tabular}

The results of the unit root tests using the ADF method is summarised in Table 2. The ADF results at natural logarithm of the CO and GDP data series (with one lag) shows that the test statistics at $5 \%$ significance level for CO and GDP are both greater than their respective critical values, and therefore, the null hypotheses of a unit root at all conventional levels of significance are rejected. This suggests that both series (CO and GDP) appear to be stationary at first difference.

\section{Granger Causality Test Result}

The concept of the Granger causality tests suggests that future values of time series data cannot predict past or present values (Granger and Newbold, 1974). Therefore, if past values of $\mathrm{CO}$ have significant contribution to the explanation of GDP, then output of the construction sector is said to Granger-cause the GDP. This entails that CO is Granger-causing GDP when past figures of construction sector have predictive power over the current figure of GDP. Conversely, if GDP is Grangercausing $\mathrm{CO}$, it is expected that GDP change must take place before a change in cO takes place. 

in Table 3.

The Granger causality test consists of estimating Equations 7 and 8, as shown

Table 3. Pairwise Granger Causality Test for CO and Nigerian GDP

\begin{tabular}{lcccc}
\hline \multicolumn{1}{c}{ Null Hypothesis } & Obs & Lag Order & F-Statistic & Probability \\
\hline $\begin{array}{l}\text { TOTAL_GDP does not Granger cause } \\
\text { CONSTRUCTION }\end{array}$ & 26 & 1 & 9.899 & 0.005 \\
$\begin{array}{l}\text { CONSTRUCTION does not Granger } \\
\text { cause TOTAL_GDP }\end{array}$ & 26 & 1 & 7.243 & 0.013 \\
\hline
\end{tabular}

Note: The null hypothesis of no causality is rejected if the $p$ value exceeds $5 \%$ significance level.

As shown in Table 3 , the $p$ values of the null hypotheses, $\mathrm{H}_{0}$ testing causality between GDP and CO are less than the $5 \%$ confidence level $(0.5 \%$ and $1.3 \%)$, indicating the rejection of the null hypotheses. This rejection means that the alternative hypotheses, $\mathrm{H}_{1}$ (GDP does Granger-cause CO and vice-versa) are accepted.

The Granger causality test results revealed that there is a bi-directional relationship between construction industry output and the aggregate economy of Nigeria. This result also indicates that the construction industry output precedes the GDP by one year, just as the GDP precedes the CO by one year. These findings also corroborated that of Oladinrin et al. (2012), which reported a pairwise relationship between the Nigerian construction sector and it's GDP between year 1990-2009.

The implication of these findings are that despite the dwindling economic situation in the country in recent times, the significance of the construction industry's contribution to Nigeria's GDP is not adversely affected. It also shows that the construction industry is one of the important sectors of the Nigerian economy that deserves a great deal of attention in order to grow and develop the country's economy, especially now that the country is seriously pursuing diversification options as a result of the fall in oil revenue. Furthermore, the construction industry has a lot of potentials that need to be exploited in Nigeria, considering the developing nature of the economy. It was argued by Myers (2008) that developing economies are characterised with large construction activities in the areas of infrastructure, housing and industrial development.

\section{Co-Integration Test}

The stationarity of the data used in this study was achieved at first difference level as discussed in the previous section. Therefore, Johansen's (1988) co-integration test was conducted to determine whether there exists a stable long run relationship between the $\mathrm{CO}$ and economic growth (GDP) in Nigeria. Table 4 presents the results.

The values of the likelihood ratios indicate no co-integration at $5 \%$ significance level and therefore the null hypothsis (which suggests the existence of a long run relationship between the two variables) is rejected. If a long run relationship exist between the variables (the GDP and the CO), then any previous influence that affect one variable in the past will also affect the other. To further confirm this factor, the normalised co-integration relation was evaluated as shown in Table 5. 
Table 4. Co-Integration Rank Test Results

\begin{tabular}{lcccc}
\hline $\begin{array}{c}\text { Hypothesised No. of } \\
\text { CO(s) }\end{array}$ & Eigenvalue & $\begin{array}{c}\mathbf{0 . 0 1} \\
\text { Critical Value }\end{array}$ & $\begin{array}{c}\mathbf{0 . 0 5} \\
\text { Critical Value }\end{array}$ & Prob. \\
\hline None & 0.540343 & 7.025523 & 15.49471 & 0.5747 \\
At most 1 & 0.003334 & 0.030059 & 3.841466 & 0.8623 \\
\hline
\end{tabular}

Note: Denotes rejection of the hypothesis at the 0.05 significance level

Table 6. Normalised Co-Integration Relation

\begin{tabular}{lcc}
\hline CO & GDP & C \\
\hline 1 & -0.079443 & 0.32969 \\
& -0.01472 & 0.14983 \\
Log likelihood & -242.3874 & \\
\hline
\end{tabular}

This result shows that there is no any long run relationship between the time series data of the variables. This therefore implies that the past effects of either series (in this case, the GDP and CO) cannot be used to explain the future characteristics of the other.

\section{CONCLUSION AND RECOMMENDATIONS}

This paper presented the findings of an empirical study of the relationship between the Nigerian construction industry output and the GDP between year 1990 to 2015. Granger causality test revealed that despite the serious challenges facing the Nigerian economy in recent times, the CO still Granger-causes the Nigerian GDP and is also being Granger-caused by the GDP. This implies that there is a correlational relationship between the growth of the CO and the GDP of the country. The two variables were also found to precede one another by one year each. However, the Johansen (1988) co-integration test revealed that there is no long run relationship between the CO and the GDP. The implication of this is that the GDP growth is greatly influenced by the growth in $\mathrm{CO}$ and vice versa. It is therefore concluded that the Nigerian construction industry still maintains its strategic significance in repositioning the country's economy.

The study findings have highlighted the need to improve the productivity and efficiency of the Nigerian construction industry, considering its potential for driving the growth and development of the economy to greater heights. This is because the efficiency and productivity of the construction industry would definitely improve the aggregate economy of the country. 


\section{REFERENCES}

Aibinu, A.A. and Jagboro, G.O. (2002). The effect of construction delays on project delivery in Nigerian construction industry. International Journal of Project Management, 20(8): 593-599. https://doi.org/10.1016/S0263-7863(02)00028-5.

Ameh, O.J. and Osegbo, E.E. (2011). Study of relationship between time overrun and productivity on construction sites. International Journal of Construction Supply Chain Management, 1(1): 56-67. https://doi.org/10.14424/ ijcscm101011-56-67.

Anaman, K.A. and Osei-Amponsah, C. (2007). Analysis of the causality links between the growth of the construction industry and the growth of the macro economy in Ghana. Construction Management and Economics, 25(9): 951-961. https:// doi.org/10.1080/01446190701411208.

Central Bank of Nigeria (CBN) (2016). GDP at 2010 Annual Constant Basic Prices. Abuja, Nigeria: CBN. Available at: www.cbn.org/statistics [Accessed on 21 July 2016].

Chen, J.J. (1998). The characteristics and current status of China's construction industry. Construction, Management and Economics, 16(6): 711-719. https:// doi.org/10.1080/014461998372006.

Dickey, D.A. and Fuller, W.A. (1979). Distributions of the estimators for autoregressive time series with a unit root. Journal of the American Statistical Association, 74(366): 427-431. https://doi.org/10.2307/2286348.

Field, B. and Ofori, G. (1988). Construction and economic development: A case study. Third World Planning Review, 10(1): 41-50. https://doi.org/10.3828/ twpr.10.1.63h4v2427v96132q.

Granger, C.W.J. and Newbold, P. (1974). Spurious regressions in econometrics. Journal of Econometrics, 2(2): 111-120. https://doi.org/10.1016/03044076(74)90034-7.

Idrus, A. and Sodangi, M. (2007). Framework for evaluating quality performance of contractors in Nigeria. International Journal of Civil and Environmental Engineering, 10(1): 34-39.

International Monetary Fund (IMF) (2016). 2016 Article IV Consultation with Nigeria. Washington DC: IMF. Available at: http://www.imf.org/external/pubs/ft/ scr/2016/cr16101.pdf [Accessed on 24 July 2016].

Johansen, S. (1988). Statistical analysis of cointegration vectors. Journal of Economic Dynamics and Control, 12(2-3): 231-254. https://doi.org/10.1016/0165$1889(88) 90041-3$.

Khan, R.A. (2008). Role of construction sector in economic growth: Empirical evidence from Pakistan economy. Proceedings: First International Conference on Construction in Developing Countries (ICCIDC-I): Advancing and Integrating Construction Education, Research and Practice. Karachi, Pakistan, 4-5 August.

Manseau, A. and Seaden, G. (eds.) (2001). Innovation in Construction: An International Review of Public Policies. London and New York: Spon Press.

Myers, D. (2008). Construction Economics: A New Approach. 2nd Ed. New York: Taylor and Francis.

Ofori, G. (1990). The Construction Industry: Perspective of its Economics and Management. Singapore: Singapore University Press. 
Ogbebor, P.O. (2002). Enhancing indigenous construction industry as a national goal in Nigerian development. In I. Akintunde (ed.). Nigerian Construction Industry: Past, Present, Problems and Prospects. Ibadan: Ibadan University Printery.

Ogwueleka, A. (2011). The critical success factors influencing project performance in Nigeria. International Journal of Management Science and Engineering Management, 6(5): 343-349.

Oladinrin, T.O., Ogunsemi, D.R. and Aje, I.O. (2012). Role of construction sector in economic growth: Empirical evidence from Nigeria. FUTY Journal of Environment, 7(1): 50-60. https://doi.org/10.4314/fje.v7il.4.

Oluwakiyesi, T. (2011). Construction Industry Report: A Haven of Opportunities. Lagos, Nigeria: Vetiva Capital Management Limited.

Omole, A.O. (2000). Surveying input to engineering projects: Need for professionalism. The Quantity Surveyor, 30: 10-18.

Oyewobi, L.O., Ibironke, O.T., Ganiyu, B.O. and Ola-Awo, A.W. (2011). Evaluating rework cost: A study of selected building projects in Niger State, Nigeria. Journal of Geography and Regional Planning, 4(3): 147-151.

Rameezdeen, R. (2007). Image of the Construction Industry. Sri Lanka: Department of Building Economics, University of Moratuwa. 